\title{
A Social Mapping of Fishermen Resource and Accessibility for Coastal Tourism Development Policy
}

\author{
Evi Sukmayeti \\ Department of Public Administration, Mataram Institute of Administrative Sciences, \\ 83134 Mataram, West Nusa Tenggara, Indonesia; evi.sukmayeti@gmail.com
}

\begin{tabular}{l}
\hline ARTICLE INFO \\
\hline $\begin{array}{l}\text { Publication Info: } \\
\text { Research Article }\end{array}$ \\
$\begin{array}{l}\text { Check for } \\
\text { updates }\end{array}$
\end{tabular}

How to cite:

Sukmayeti, E. (2019). A Social Mapping of Fishermen Resource and Accessibility for Coastal Tourism Development Policy. Society, 7(2), 116-134.

DOI : 10.33019/society.v7i2.101

Copyright (C) 2019. Owned by Author(s), published by Society

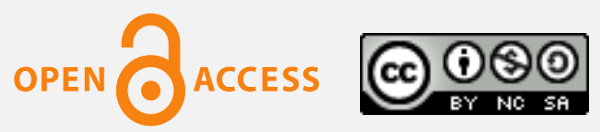

This is an open access article.

License: Attribution-

NonCommercial-ShareAlike (CC BY-NC-SA)

\begin{abstract}
Many fishermen in Indonesia have not fully utilized marine resources properly. However, the government has several ways to improve the welfare of fishermen in other sectors than the fisheries; one of them is connecting between fishermen, coastal and tourism. Meninting of West Lombok is a strategic coastal village for the tourism sector. This village has started to develop tourist destinations since 2011, unfortunately, there is no data on fishermen as a real interest group. This study develops a research pattern on fishing communities which generally discusses the social resources of fishermen and the political aspects of fishing communities separately. This study used a qualitative approach to the social mapping method. Data obtained through interviews and observations of purposively selected informants. The data related to fishermen resources are in maps, followed by an analysis of their accessibility to policy. Spatial aspects strengthen their social resources, interests, and accessibilities to coastal tourism development. The results show that the social resources of fishermen of Meninting Village are unevenly distributed in five dusun (sub-villages). Indicators shown are; capital ownership, mastery of knowledge and skills, ownership of production equipment, use of science and technology, ability to diversify production, fishermen's sociopolitical relations and ability to recognize the economic prospects of coastal tourism. Fishermen who live in areas directly facing the sea have better social resources and firmer interests in coastal development. The accessibility of fishing groups is limited in the development policy. Only fishermen in sub-village located in a coastal area can show themselves as defenders. While the fishermen who live far from the beach tend to be latent or even apathetic. This study recommends the need for other social mapping studies on the characteristics of coastal
\end{abstract}


Received: October 21, 2019;

Accepted: December 4, 2019;

Published: December 25, 2019; communities and the need for the government to use the social mapping information of fishing communities to formulate policies that contain regional aspects in coastal tourism development.

\section{Introduction}

The Government of Indonesia assumes that many fishermen communities have not utilized the marine wealth yet. The Ministry of Marine Affairs and Fisheries of the Republic of Indonesia (Indonesian: Kementerian Kelautan dan Perikanan Republik Indonesia or KKP) and the Ministry of Tourism of the Republic of Indonesia (Indonesian: Kementerian Pariwisata Republik Indonesia or Kemenpar) accord on the assumption (Mongabay, February 8, 2017). it happens to the fishermen community in West Nusa Tenggara (Indonesian: Nusa Tenggara Barat or NTB). In NTB, more than 74,000 fishermen until 2012 (compiled from Satu Data Indonesia, 2012) faced with the fact that nearly 14,000 poor household's livelihood in the capture fisheries sector (Badan Pusat Statistik, 2012). Therefore, the Government of Indonesia through KKP seeks some solutions to improve their welfare. In 2017, KKP succeeded in increasing the average fishermen's income to $\mathrm{Rp} 3.16$ million per person/month (Berita Kementerian Kelautan dan Perikanan Republik Indonesia, 12 January 2018). If referring to the Central Statistics Agency (Indonesian: Badan Pusat Statistik or BPS) standard for the amount of fishermen's daily expenditure the poor category is under Rp. 600,000/month (Keluargaharapan.com, 2 October 2016), these figures indicate that fishermen can no longer be categorized as poor.

In the last three years, Lombok Island has scored international achievements in several halal tourism (tourism that is more aligned with Islamic Law and traditions) categories. Even though the halal tourism concept that is echoed is not yet firm and is supported by the reality on the ground (Scott, 2017), at least, this has succeeded to trigger the local government and the community enthusiasm to take advantage of the economic value momentum.

Meninting Village is located at the entrance of the Tourism area, Senggigi, Lombok Island, West Nusa Tenggara, Indonesia. The village has a fairly complete marine tourism potential such as Kali Meninting estuary and beaches along the west that directly faces Bali island. It is a very strategic location to develop as a tourist destination because it has an area to be traversed by tourists visiting Senggigi and also it is bordered by Mataram City so it is easier and faster visited. Since 2011, Meninting Village has been pioneered as a culinary tourism location. In 2017, the Local Government will hold the Bekele Tuna Festival which will become an annual event. This activity is expected to make Meninting Village become a crowded area as a new tourist area (Pos Bali, December 17, 2017). Meninting Village has vast coastal potential and challenging waves, also strategic for surfing tourism locations (Radar Lombok, October 30, 2017). For those reasons, the local government is seriously preparing for the development of tourist areas, including the Meninting Village that will have an impact on the 30 residents' houses relocation in Dusun Kongok (Radar Lombok, February 24, 2017).

However, there are concerns about the position of the local community who are merely spectators of government policy because they are defeated by investors and foreign workers 
(Indonesian: Tenaga Kerja Asing or TKA). Some heads of villages asked the local government to oversee the foreign workers in their area (Batulayar News, 17 February 2016).

Unfortunately, the Meninting Local Government does not have a record of the number, location of settlements, owned resources and so on regarding fishing communities in the area. The identities of the fishermen groups that represent information about the whereabouts of the fishermen are also not well-archived. The Meninting Local Government stated that this was because the fishermen groups could only be known to them in real terms when there was financial assistance or tools from the government or when the fishermen groups formed themselves and asked for a certificate for the administration of aid proposals. After the relief program ended, several fishing groups dispersed. Besides, certificates issued by the Local Government were not archived. The fishermen and fishermen groups are not well organized if faced with the existence of a coastal tourism destination development program in Meninting that has been initiated since 2011, causing the low involvement of fishing communities as the dominant community inhabiting coastal areas in development activities and of course has an interest in the development of their living space. The plan to utilize the coastal area of Meninting by the Local Government for the development of coastal tourism should include the people who inhabit the area. Community potential must be mapped.

Academically, many other disciplines use social mapping methods. In developmentthemed studies, for example, social mapping usually combines social and spatial aspects as well as related. Social mapping methods help research related to governance area in understanding the equality, efficiency, and transparency (Alemie et al., 2015). In specific coastal area research, this method is used to assist spatial marine management planning that is prone to conflicting uses (Moore et al., 2016). The social mapping of coastal tourism areas in Indonesia is still not of primary importance. Research conducted in the Regency of West Coastal formulates zoning potential marine ecotourism (Herison et al., 2018). While research conducted in Kampung (smaller than sub-village) Pasie Nan Tigo, Padang City, West Sumatra, Indonesia, resulted in the zoning threat of disaster vulnerability to tourist areas of fishing villages (Haryani, 2014). Both studies utilize mapping to formulate the utilization of the physical environment of an area for tourism activities. While this research aim to study the social characteristics of coastal communities especially fishermen in terms of resources and their response to coastal tourism development. Social mapping of fishermen groups in Meninting can be used by the Local Government and users of research results as a description of the potential of fishermen according to their living space where tourism development will be centered.

Social Mapping has several aspects including; statistically, anthropologically and netlivelihood-oriented (Safiullin et al., 2015). Safiullin et al., (2015) provide examples of social mapping applications in geographic maps that contain social categorization symbols that are connected. This method is different from the example exemplified by Saribanon, et al., (2015) who documented a social mapping study of the Gilireng area where the outcome was in identifying respondents' social aspects separately between regional and social aspects of the respondents. However, both of these social mapping studies show that the geographical aspects of the map and the social aspects studied in social mapping are two aspects that must be displayed and related to each other.

If related to the benefits of social mapping of public policy, then one important thing is when the public policy involves a relatively small community and has certain territorial aspects. Every public policy has its target group. A policy that has social value will certainly affect the social aspects of its territory and can be influenced by social interests as well. Dunn

Copyright (C 2019. Owned by Author(s), published by Society. This is an open access article under CC-BY-NC-SA license.

https://doi.org/10.33019/society.v7i2.101

118 
(2000) states that the target group is not necessarily the group that will benefit, it may even be that the target group receives losses or becomes a group of sufferers. In conducting social mapping research on the phenomenon of participation in public policy, analysis of the target group cannot be avoided. Analysis of the target group (which will be presented in a mapping analysis) is needed with the aim to (1) understand the social differences in a population (based on gender, social strata, age, ethnic identity) and other things in the community so that the community can participate (in public policy); (2) understand the target group's perceptions and behavior towards other stakeholders and institutions, and to develop realistic strategies for participation; (3) measure the risk and impact of a program idea or strategy (Forster and Osterhaus, 2011). Therefore, social mapping of fishermen's social resources will deliver an understanding of differences in fishermen's social resources and differences in the behavior and perceptions of fishermen towards coastal tourism development according to the area of residence.

The results of this study aim to (1) describe the social map of the resources of the fishing communities of Meninting Village according to the area of residence, and (2) access the fishermen according to the spatial distribution of the resources they have, as stakeholders in the policy of developing tourist destinations in the Meninting Village. This research continues the starting point of previous studies which generally only describe the fishermen resources and their impacts experienced as the implications of marine or coastal tourism development.

\section{Literature Review}

\section{A. Fishermen Resources}

Fishermen in coastal areas are the most frequently encountered communities. For this community, the closeness of their homes and the daily interactions with the sea give birth to the most tangible understanding of making a living.

The fishing community has a life side that can be studied in several aspects. From the political aspect, research conducted by Royandi et al., (2019) on fishermen in Palabuhanratu, West Java, Indonesia, shows that fishermen are one of the actors who helped build power through rights-based access mechanisms, and access structures based on structures and social relations. The basis of capital, market, technology, knowledge, social identity, authority, and patron-client power are explained as fishermen's resources in accessing marine resources.

In addition to socio-cultural conditions, research on fishing communities mentions some characteristics of fishing communities such as participation in social organizations, use of technological tools, knowledge, and skills passed on to their offspring, income, family expenses, living conditions, health and education of children (Fitriyah \& Widodo, 2016). While other studies see that fishermen community resources are reflected in the ownership of capital and means of production as well as business relationships between fishermen which are illustrated in three strata namely labor fishermen (lower layer), owner fishermen (middle layer) and financiers (upper layer) (Saleha, 2013). These characteristics can be a resource of the fishing community in influencing policies related to their livelihood and life.

This study will describe the social resources fishermen ownership in Meninting village to access the development policies in of (1) capital control as the basis for economic influence and interests, (2) knowledge and skills to describe production capacity, (3) use of Science and Technology (Indonesian: Ilmu Pengetahuan dan Teknologi or IPTEK) to describe the social capacity of individual fishermen, (4) ability to identify economic prospects to describe aspects of the interests of fishermen, (5) production diversification results to illustrate economic capacity as producers in the marine tourism sector, (6) production means ownerships to 
describe their economic strata related to influence on policy, and (7) Political economic relations to describe their influence activities and interests in the policy system.

The fishing community shows a variety of interactions with the development itself in developing marine or coastal tourism, especially utilizing natural resources and the coastal environment. Firstly, the communities can be the main actors in the development of tourist destinations as in Agam District, West Sumatra, Indonesia (Zamzami, 2016). Secondly, the fishing community has become a passive actor, involved in the development of tourist destinations at the instigation of other parties such as the government or investors such as in Pasie Nan Tigo, Padang City, West Sumatra, Indonesia (Huda, 2016). Thirdly, the fishing community is a completely separate actor from the coastal tourism development activities where they live. This is as identified in the development of Tanjung Benoa marine tourism, Bali Province, Indonesia, which causes the fishermen a decrease in the quantity and quality of catches and the intensity of fishing (Pratiwi, 2014).

\section{B. The Stakeholders Accessibility to Public Policy}

The analysis of Stakeholders needs to determine the accessibility or ability of actors to access the benefits of public policy. The analysis provides a role to collect more complete perspectives on sectors and elements influenced by policy, strengthen the position of those who have opposition, increase organizational credibility and deliver parties involved in public policy in successfully achieve their goals (Community Tools Box, 2014).

In identifying stakeholder accessibility to policies, it is necessary identifying: (1) the personal interests of actors, (2) the level of knowledge of policy issues, (3) resources, (4) capacity to mobilize resources, and (5) position on the issue; support, neutral or reject (abstracted from the Policy Stakeholders Analysis Tool by Policy Circle, 2019). The categorization of stakeholders if related to their accessibility is very relevant using the quadrant formulated by the University of Kansas Center for Community Health and Development namely promoters, defenders, latent and apathetic as can be seen in Figure 1 (Center for Community Health and Development University of Kansas, 2014). Promoters are those who have high importance and influence on policy. Defenders are actors who have a high interest in policy but can only influence a little. Meanwhile, latent represent those who have high influence but unfortunately have few interests, and apathetic describes those who have an interest as well as a small influence on policy. As a quadrant, the four categories mentioned can experience dynamics so that one category can develop into another.

Tourism development policies always include activities to develop tourist destinations. Cooper, Fletcher, Gilbert, Shepherd, and Wanhill indicated five main components of developing tourist destinations: (1) Objects and Attractions, (2) Accessibility, (3) Amenities or supporting facilities and tourism support, (4) Ancillary or other supporting facilities, and (5) Institutional (Sunaryo, 2013). The five components will result in successful tourism development if managed properly.

Good governance in tourism development of the aspect of involving actors outside the government must at least contain principles that describe supervision and control, active engagement, partnerships and accommodation of community aspirations (Sunaryo, 2013). If in the opinion of tourism production according to Yoeti there are 3 (three) minimum destination requirements namely something to see, something to do, and something to buy (Tatali et al., 2018), then the local community has the potential in providing all of the three. 
Figure 1

Stakeholders Mapping

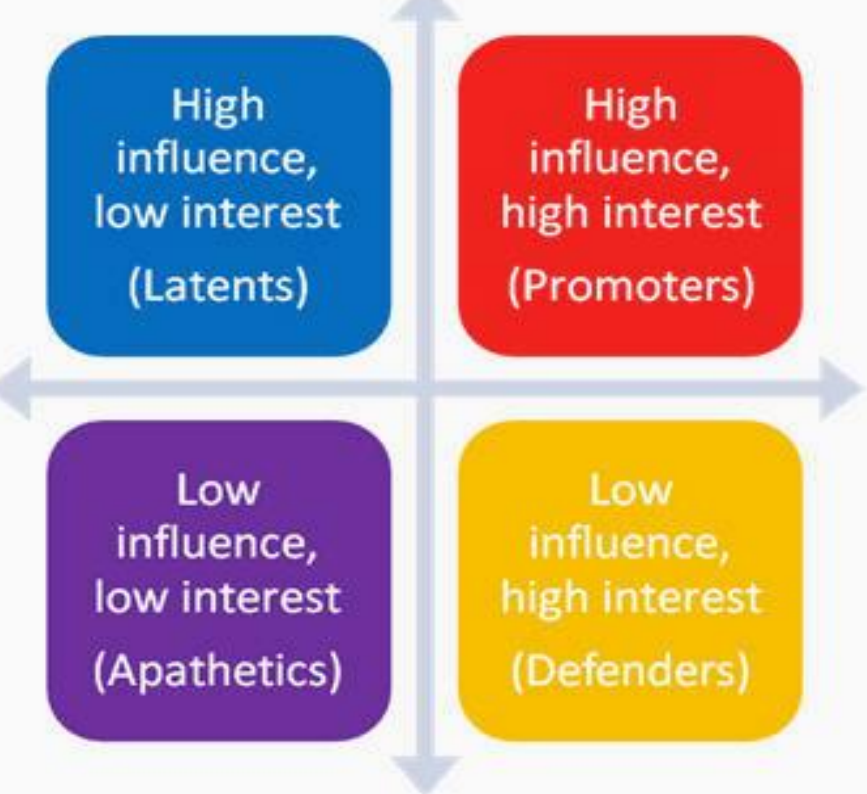

Source: (Community Tools Box, 2014)

\section{Research Methodology}

Meninting Village is one of the coastal villages located in the Batulayar District, West Lombok Regency. As one of the coastal areas in West Nusa Tenggara Province, this village is very close to tourism activities and locations on Senggigi Beach. Meninting Village consists of five sub-villages (locally known as Dusun), they are; Dusun Meninting Buwuh, Dusun Kongok, Dusun Peresak, Dusun Tegal, and Dusun Pelempat. All the five dusun, only two dusun namely Meninting Buwuh and Kongok are directly facing the western coastline of Lombok Island. Also, the village is administratively very close to the center of the provincial capital. Meninting Village is passed by Meninting River which empties into the Lombok Strait separating Lombok Island from Bali to the west. Kali Meninting becomes the natural boundary of Meninting Village and the city administrative area. This study uses a qualitative approach to the method of collecting and presenting data on social maps. Social Mapping also can be used as a method in exploring the social structure of the community related to their participation in public policy. This method produces research output in visualizing the location of households and the distribution of social characteristics of the community (World Bank, 2007). The World Bank stated that data that could be illustrated by the visualization included community layouts, infrastructure, demographics, ethnolinguistic groups, health patterns, welfare and so on. Meanwhile, what can be identified from social mapping is the criteria of local social groups and measuring the distribution of resources between them. The World Bank notes that social mapping is appropriate for small community studies but will be very complex if the number of households studied is greater.

Social mapping is unlike physical mapping. Social mapping is more about compiling reports with local communities (Kalaisevan \& Dongre, 2012). Social mapping also use to identify the socio-cultural conditions of a community, including: (1) The dominant values that

Copyright (C 2019. Owned by Author(s), published by Society. This is an open access article under CC-BY-NC-SA license. https://doi.org/10.33019/society.v7i2.101

121 
are adopted to be able to move the community; (2) Social forces that have the potential to change their communities; (3) The character of the community when facing social interventions; (4) Information and communication patterns; and (5) Environmental factors that influence their attitudes and behavior (Wiratma, 2010). So far, studies that use social mapping as a method are more related to geographical or scientific fields that require spatial identification. While studies in the social field generally end in social maps exploration without making it an effort to understand the position of the community in the policy process and formulate it as a public policy recommendation.

The object under study is the resources of the fishing community on the coast of the Meninting Village which is considered to be a resource base to influence and be influenced by village development programs oriented to new tourist villages other than the Senggigi area in West Lombok. The data generated are in (1) Spatial data of fishermen's social resources, and (2) Socio-spatial categories of fishermen as stakeholders in tourism development policies in Meninting Village. Besides, government and public documents regarding the social aspects of the fishing community on the coast of Meninting are used to support triangulation activities.

Data were collected by (1) observing the spatial environment of the fishing community's residence, socio-economic aspects that can be sensed through recordings, photographs or can be described narratively, and (2) interviews to identify the social categories of fishing communities related to their position as a stakeholder in the village development program. Interviews were conducted with some selected informants purposively with categories; (1) geographical representation of residence, (2) ownership of economic resources, (3) social aspects needed to influence policy and possessed to be said to have an interest in policy and (4) informant capacity in the policy process. Then the data is presented in the social map that explains the distribution and social conditions of the distribution associated with the village development program.

In identifying fishermen resources, researchers conducted interviews with twenty-three fishermen and four groups of fishermen. Twenty-three fishermen resided representing each dusun where they resided. While four fishermen groups came from Dusun Meninting Buwuh, Dusun Pelempat, and Dusun Peresak. Each group of fishermen has diverse members, ten to thirteen people. There is one group of fishermen that is a fraction of another group. The informants were determined from information developed from the narrative of each dusun head, where three dusun heads were also fishermen or had livelihood as fishermen. Besides, there are informants met incidentally on the anchorage port.

\section{Results and Discussion}

\section{A. Meninting Fishermen Resources}

The Local Government of Meninting Village does not have any detailed data of fishermen. The number of fishermen and their groups in Meninting Village is very volatile. Dusun (subvillage) Tegal is a sub-village that shows an extreme absence of fishermen groups, even though there are some people as fishermen. As a result, its community members joined with fishing groups in other dusun. Dusun Meninting Buwuh is a sub-village that has the largest number of fishing groups. It is located in an area directly adjacent to the beach. The economic activities of the community are specifically related to the sea. At the time of this research, informants in this sub-village could mention each other until the data recorded were four groups. There are several causes of fluctuations in the number of fishing groups: (1) Ability to capitalize fishing activities, (2) Long-term expectations of fishing livelihood, (3) Pragmatic reasons for just obtaining certain funds or material assistance, and when the funds or assistance have been 
obtained then the group exchanging member formations or even stopping activities, and (4) Conflicts between members.

The lack of land use characteristics such as paddy fields or plantations makes the people attach to the livelihood as fishermen are higher. The livelihoods and residences on the coast of Meninting which is inherited by parents make the interests of the sea very clear.

Their social resources ownership varies according to their form and value related to village development policies. The social map of capital control by Meninting fishermen as in Figure 2 shows how fishermen who live on the coast, such as in Meninting Buwuh and Kongok, have better capital capacity. This is demonstrated by the experience of accessing capital assistance from non-banking financial institutions, it is savings and loan cooperatives (locally known as koperasi).

Also, there are fishery auctions who have an individual capital capacity that is well known by fishermen such as in Dusun Kongok. Meanwhile, the other three dusun do not yet have adequate capital access and only depend on the group's internal support system, or choose not to go to sea for a while, and even stop being fisherman.

\section{Figure 2}

Social Mapping of Fishermen Capital based on Dusun (sub-village)

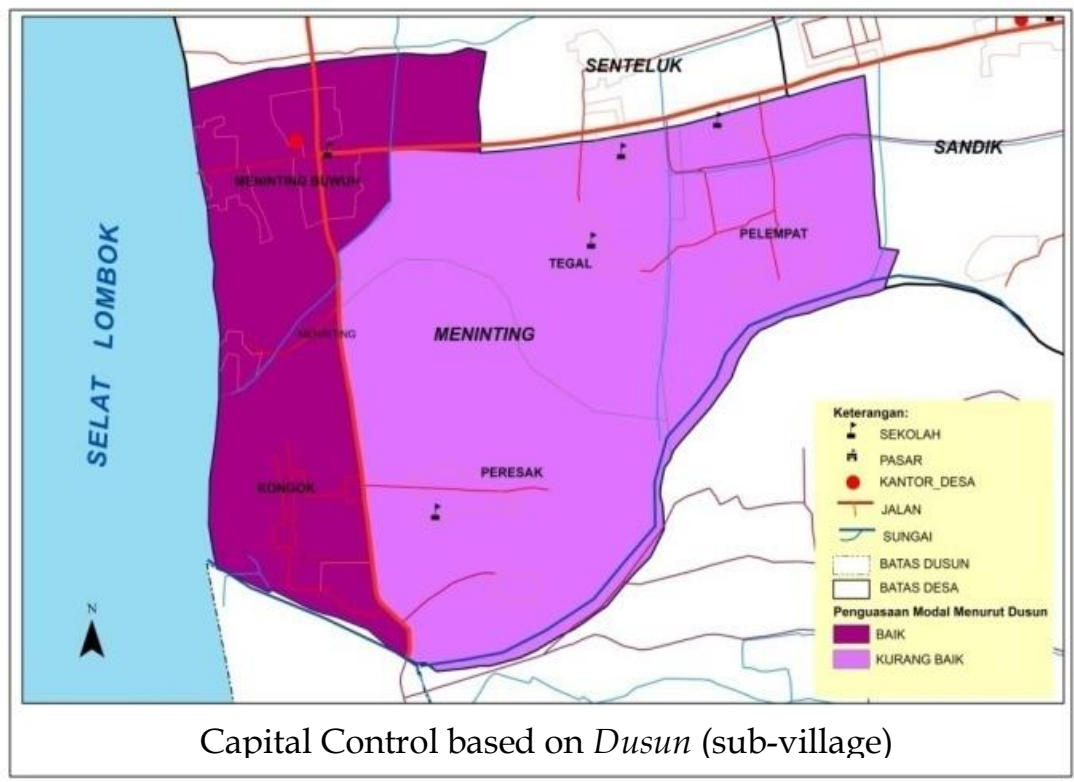

Information

Sekolah $=$ School

Pasar $=$ Traditional Market

Kantor Desa $=$ Village Office

Jalan $=$ Street

Batas Dusun $=$ Sub-Village Boundaries

Batas Desa $=$ Village Boundaries

Capital Control based on Dusun (subvillage)

Baik $=$ Good

Kurang Baik $=$ Not Good

Source: (Primary Data, 2019)

Further, the informant described that a fisherman household can become a fishing owner (middle class) when he is directly involved in fishing production activities as well as financiers (upper class) when he becomes an auctioneer. There is no data shows that labor fishermen (lower class) in Meninting Village that can reach the middle and upper classes, but instead face the risk of stopping at all when capital lack face together with the declining of the fishing season. Three informants who cited the reasons to stop fishing activities are the absence of a daily capital of at least 75 thousand rupiahs to purchase boat fuel, while the catching sale does not cover capital or may not bring any results at all. Even, when they joined a group of fishermen, they could use a boat belonging to the group. In contrast to fishermen workers those are not joined in groups which their livelihoods depend on the boat owner.

Fishermen who live in the two dusun directly facing the sea thus show good capital capacity. The high importance of the maritime economic value where their houses face the sea

Copyright (C 2019. Owned by Author(s), published by Society. This is an open access article under CC-BY-NC-SA license. https://doi.org/10.33019/society.v7i2.101 
is shown by the consistency of livelihood as fishermen and their behavior in maintaining economic activities through the capital.

To be a fisherman requires a learning process. The Meninting fishermen tell us that the knowledge and skills that they use to sail and produce satisfying catches come from (1) Parental or ancestral inheritance, based on lineage or ethnicity, where the background of social learning in tribal communities is very strong, for example, the Bugis tribe, which specifically inhabiting in Dusun Meninting Buwuh on the coast of Meninting (2) Self-taught, where fishing activities by fishermen in this category are obtained from learning in fishermen groups such as fishermen in Dusun Pelempat, Dusun Tegal and Dusun Peresak, (3) Other formal institutions such as through training and mentoring provided by the government so that the skills and insight of fishermen regarding the sea increases. In the distribution of fishermen according to the mastery of knowledge and skills, as shown on the map in Figure 3, it cannot be denied that the emergence of information related to social mapping compares to the ethnicity.

Figure 3

Social Mapping of The Fishermen Mastery of Knowledge or Skill based on Dusun (sub-village)

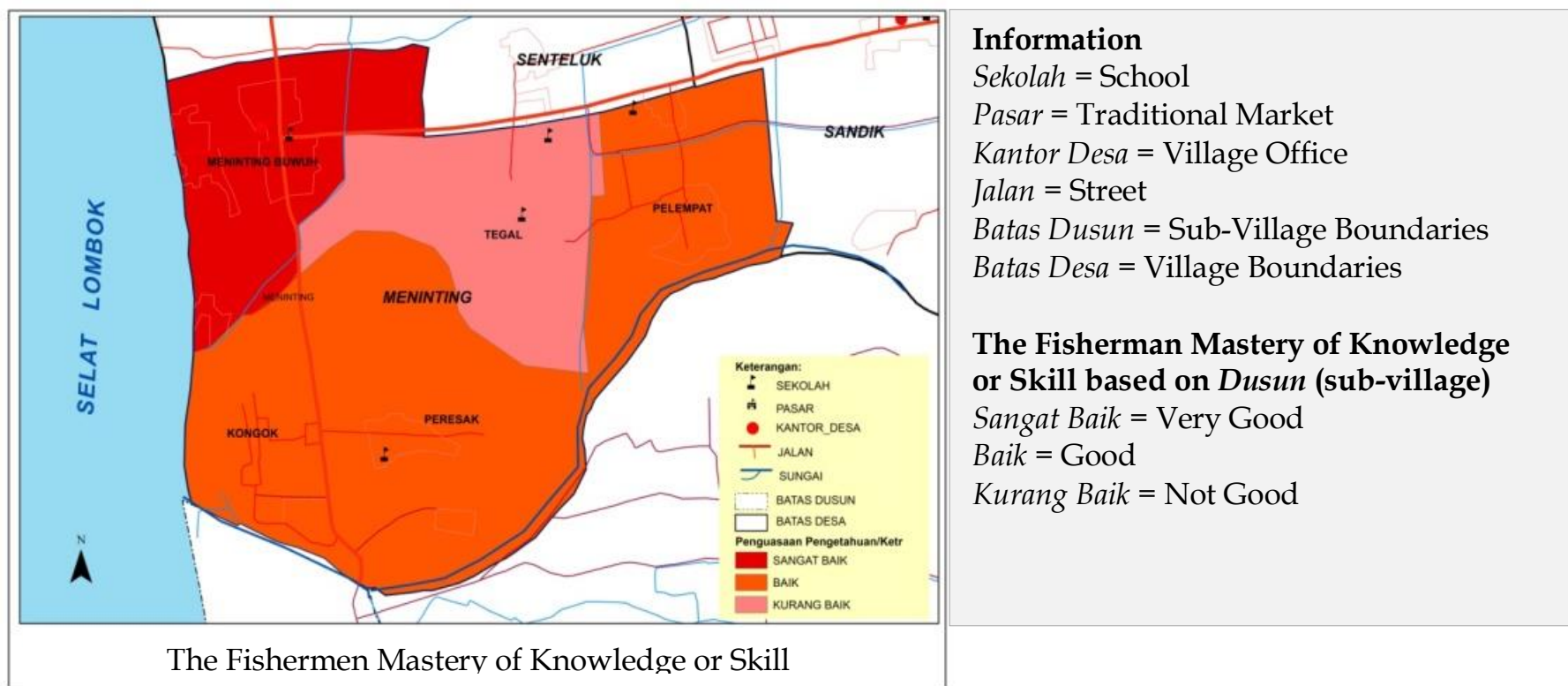

Source: (Primary Data, 2019)

The successful fishermen exemplified by the community of Dusun Meninting Buwuh, those who are descendants of Bugis ethnic who possess excellent knowledge or skills. The informant explained that they deal with the sea since their birth, bequeathed to them knowledge of the direction of the compass and predictions about the type and number of fish that can be caught. Neither is knowledge about ocean currents that have been passed down from generation to generation in fishing families where they were born and grew up. That way they can effectively and efficiently mobilize resources to catch fish according to certain seasons.

They use Science and Technology (Indonesian: Ilmu Pengetahuan dan Teknologi or IPTEK) to support fishing activities that are closely related to the acquisition of knowledge and skills. Using modern communication tools such as mobile phones and knowledge-based analysis is to recognize season and wind that determine the number of fish and so on varies between fishermen from one village to another. Some fishermen who become informants are mostly illiterate and they are hard to find on the beach when they are anchored as usual. One way they usually do is to look for the existence of a boat among fellow fishermen or other groups. Some

Copyright (C 2019. Owned by Author(s), published by Society. This is an open access article under CC-BY-NC-SA license. https://doi.org/10.33019/society.v7i2.101 
of them are still walking from the house to the beach rather than motorized vehicles. Financier fishermen socially control and use science and technology well, while laborers and owner's fishermen only control a portion of the science and technology needed to support fishing activities or improve their welfare. Some fishermen don't even use science and technology at all because of a lack of ownership. Figure 4 shows how the difference in the use of science and technology in the fisheries production activities of each sub-village.

The existence of fishermen who are relatively consistent at sea in the Dusun Meninting Buwuh, besides being related to the political-economic relations resources of fishermen in the sub-village, supports the entry of science and technology related to fishing activities. The knowledge-sharing that they obtained came from the background of living space directly bordered by the sea which conditioned them to gain new knowledge related to fishing and assistance obtained from outside institutions in of training.

Figure 4

Social Mapping of Fishermen Technological use based on Dusun (sub-Village)

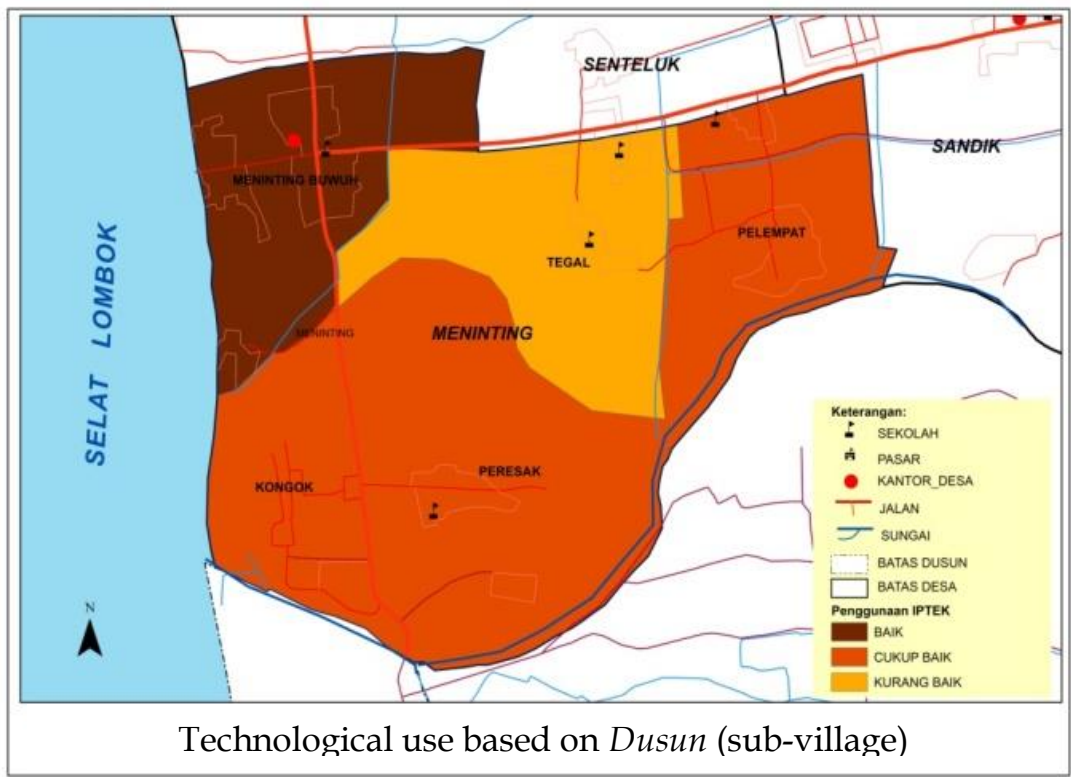

Information

Sekolah $=$ School

Pasar $=$ Traditional Market

Kantor Desa = Village Office

Jalan $=$ Street

Batas Dusun $=$ Sub-Village Boundaries

Batas Desa $=$ Village Boundaries

Technological use based on Dusun (subvillage)

Baik = Good

Cukup Baik = Pretty Good

Kurang Baik $=$ Not Good

Source: (Primary Data, 2019)

Not all fishermen in the five dusun recognize or can grasp the economic opportunity from developing the tourism sector in their village. Only fishermen in the two dusun directly bordering the coastline, namely Dusun Kongok and Dusun Meninting Buwuh, have a vision of the economic opportunity of tourism for their profession as in Figure 5.

Fishermen in the dusun of coastal areas are more aware of the existence of an economic tourism opportunity because these two dusun are directly in contact with tourism development plans, especially culinary or sport and nature tourism, both funded by villages, as well as the state and district governments. Even the people in Dusun Kongok since 2017 have been socialized about the plan to develop their settlements into estuary tourism objects which according to local figures will mimic the Venetian-style boat attractions in Italy. But unfortunately, fishermen and processing groups that are generally composed of women in fishing households have not yet decided on their response to the opportunity. Some of the reasons put forward are the lack of product processing expertise, the lack of capital to produce a variety of captured products and the reluctance to speculate or satisfaction with their current economic conditions. In recognizing economic opportunities, even though owner fishermen

Copyright (C 2019. Owned by Author(s), published by Society. This is an open access article under CC-BY-NC-SA license. https://doi.org/10.33019/society.v7i2.101 
have the resources to be involved in economic tourism activities, this group of fishermen does not necessarily recognize opportunities or take opportunities to improve welfare. Reluctance to try to do new business activities beyond what they normally do is the main reason.

\section{Figure 5}

Social Mapping of Fishermen Ability to recognize the prospect of their area based on Dusun (sub-village)

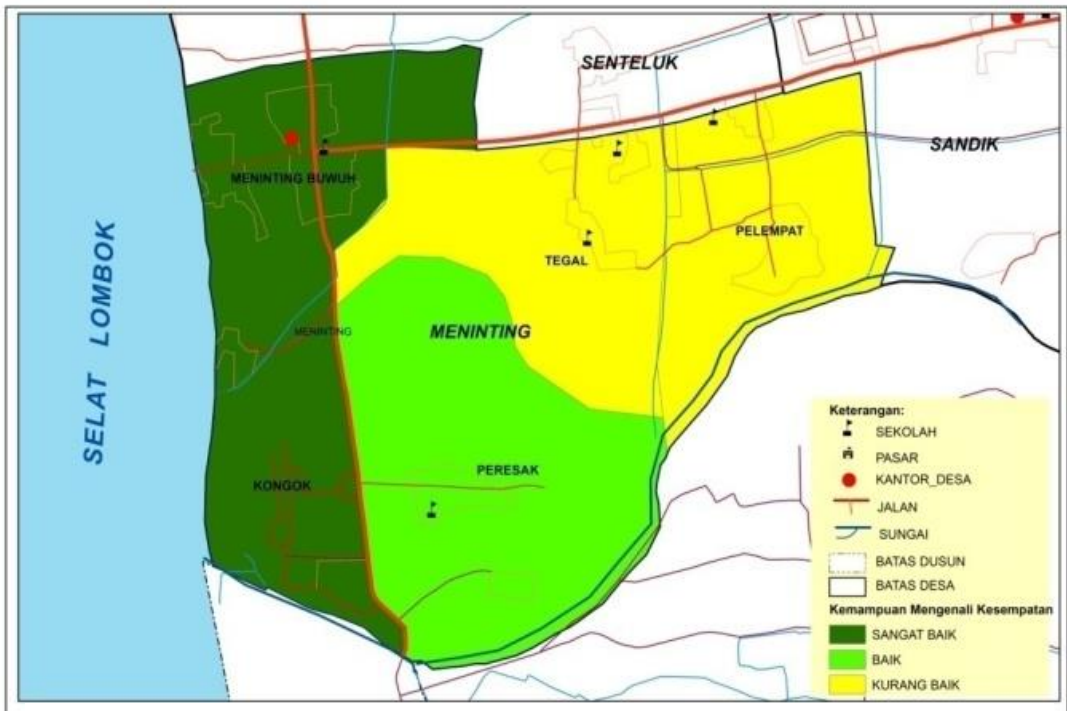

Fishermen Ability to recognize the prospect based on Dusun
Information

Sekolah $=$ School

Pasar $=$ Traditional Market

Kantor Desa = Village Office

Jalan $=$ Street

Batas Dusun = Sub-Village Boundaries

Batas Desa $=$ Village Boundaries

Fishermen Ability to recognize the prospect based on Dusun (sub-village) Sangat Baik = Very Good

Baik $=$ Good

Kurang Baik $=$ Not Good

Source: (Primary Data, 2019)

In terms of diversification of fishermen production, it was found that only one dusun that has a catch processor, both in groups of women and individuals or fishing households, who carry out the production process into a variety of products as depicted on the map Figure 6. Dusun Meninting Buwuh has a group that producing catches by boiling and roasting. While in other dusun it is identified that the production process is only in boiling (like in Dusun Kongok where the majority of fishermen specialize in fish caught in of Tuna) or even sold fresh out without the process of adding economic value to their catches.

Dusun Meninting Buwuh which is located right on the beach which is a tourist attraction of Montong Beach supports the diversification of catch products. In this village, it is very easy to find smoked or grilled fish stalls that are sold by fishermen mothers in the morning and evening. This dusun is open due to good road access and is supported by road routes along the coast. While in Dusun Kongok, which also borders the coast, smokers or grilled fish sellers were found in addition to fish processing production centers. Dusun Kongok does not have adequate access to public roads and the coast has not been managed so that it presents an interesting view because at the end of the entrance to the dusun visitors will only find dead-end areas such as fishing huts and boat mooring locations. Moreover in Dusun Kongok, fishermen are specialized in Tuna Fish catch.

Labor fishermen with low production capacity mostly sell their catches in fresh condition to collectors. While owner fishermen and financier fishermen can further diversify in of boiled or grilled fish, even though there are collectors who also sell their catch in fresh condition. 
Figure 6

Social Mapping of Fishermen Product diversification based on Dusun (sub-village)

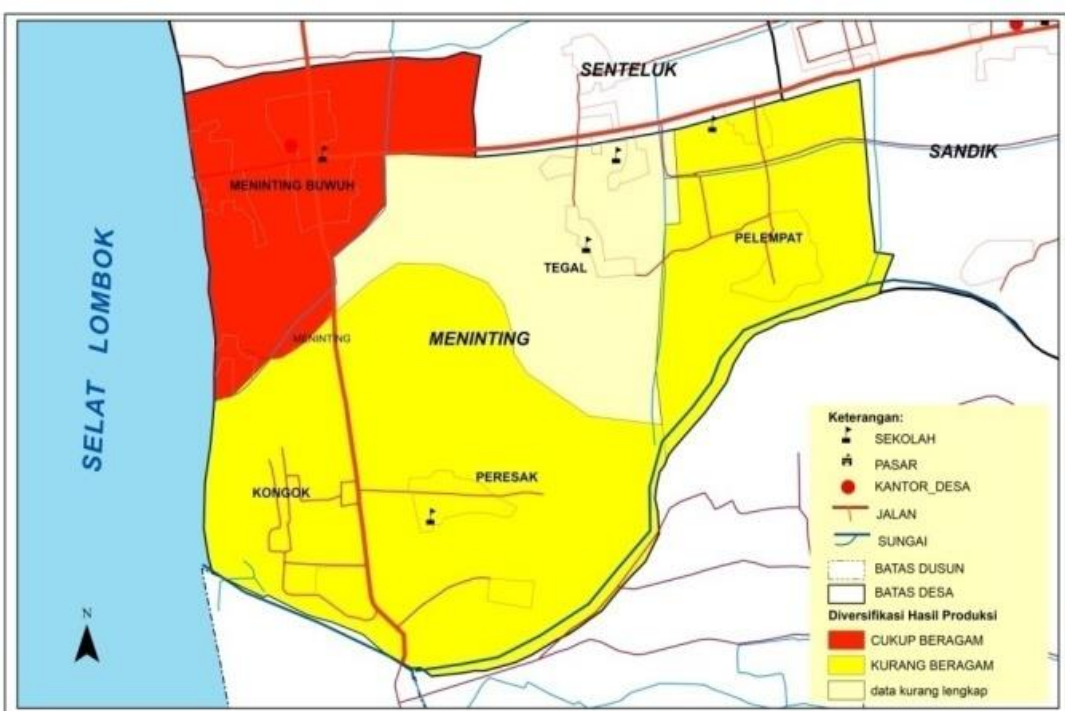

\section{Information}

Sekolah $=$ School

Pasar $=$ Traditional Market

Kantor Desa $=$ Village Office

Jalan $=$ Street

Batas Dusun = Sub-Village Boundaries

Batas Desa $=$ Village Boundaries

Fishermen Product diversification based on Dusun (sub-village)

Cukup Beragam $=$ Quite Diverse

Kurang Beragam = Less Diverse

Data kurang lengkap $=$ Data Incomplete

Fishermen Product diversification based on Dusun (sub-village)

Source: (Primary Data, 2019)

The fishermen own their production means are vary. Based on the identification of observations and interviews in the field, fishermen residing in Meninting Buwuh village have production equipment in boats and various fishing gears consisting of boats of various sizes and types of fish that can be captured by these tools. Meanwhile, fishermen in Dusun Peresak and Dusun Pelempat are mostly fisherman laborers or do not have boats and fishing gears so that they are more often identified as seasonal labor fishermen and even stop at sea due to the lack of tools. This is as mapped in Figure 7.

Figure 7

Social Mapping of Production Means Ownership based on Dusun (sub-village)

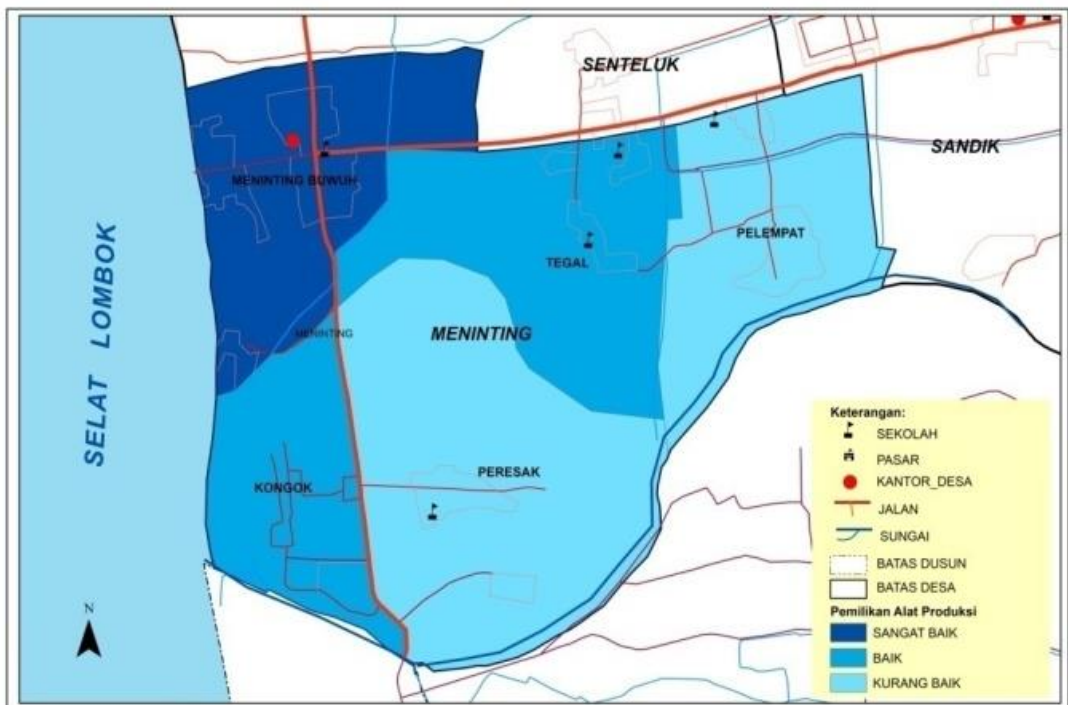

Production Means Ownership based on Dusun (sub-village)

\section{Information}

Sekolah $=$ School

Pasar $=$ Traditional Market

Kantor Desa = Village Office

Jalan $=$ Street

Batas Dusun = Sub-Village Boundaries

Batas Desa $=$ Village Boundaries

Production Means Ownership based on Dusun (sub-village)

Sangat Baik $=$ Very Good

Baik $=$ Good

Kurang Baik $=$ Not Good

Source: (Primary Data, 2019)

Copyright (C 2019. Owned by Author(s), published by Society. This is an open access article under CC-BY-NC-SA license. https://doi.org/10.33019/society.v7i2.101 
In the context of the policy system, characteristic patterns of economic-political relations. Capital interactions, use of production equipment, trade-in fishing and production, and communication and access to government policies towards the central government in Meninting Village are quite distributive. The identified dusun does not have a fishermen group, namely in Dusun Tegal, where fishermen who reside in this dusun are even linked to joining a fishing group in another dusun so that it is not difficult to gain access to large capital such as financial institutions or government programs. Dusun Meninting Buwuh and Dusun Pelempat provide opportunities for fishermen and their groups to provide resources provided by the government and financial institutions such as boat assistance, fishing equipment or financial capital, including opportunities to contribute to the livelihood program of the Meninting Local Government. Figure 8

\section{Figure 8}

Social Mapping of Political Economy Relations based on Dusun (sub-village)

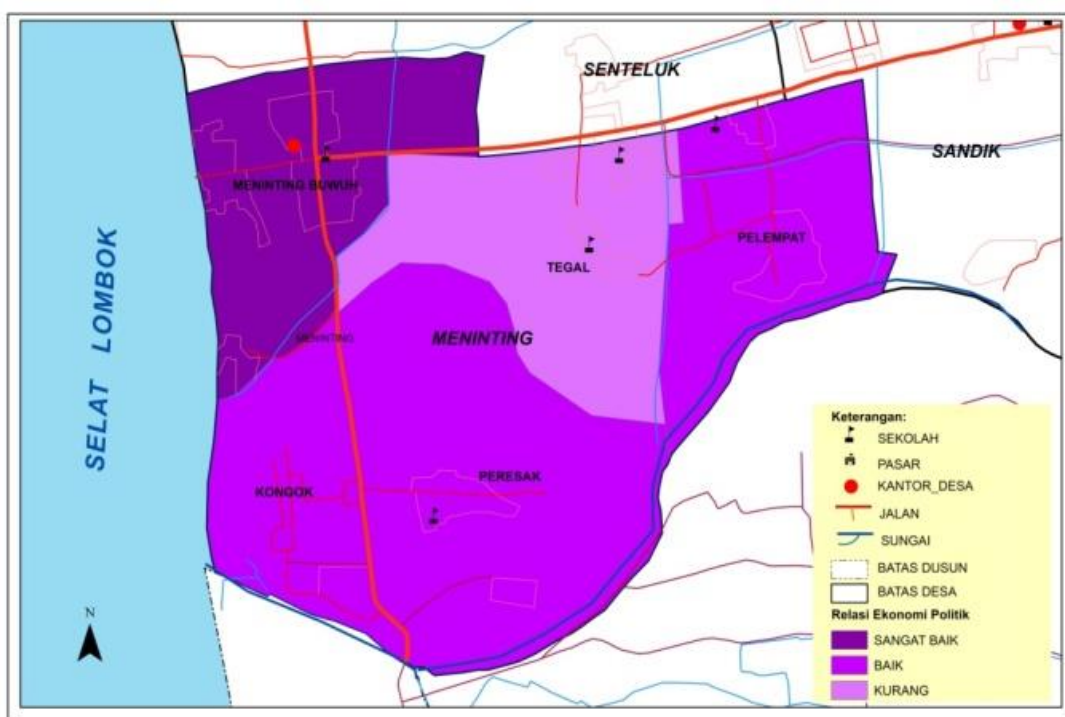

Political Economy Relations based on Dusun (sub-village)
Information

Sekolah $=$ School

Pasar $=$ Traditional Market

Kantor Desa = Village Office

Jalan $=$ Street

Batas Dusun = Sub-Village Boundaries

Batas Desa $=$ Village Boundaries

Political Economy Relations based on

Dusun (sub-village)

Sangat Baik = Very Good

Baik $=$ Good

Kurang Baik $=$ Not Good

Source: (Primary Data, 2019)

In terms oof social and political organizations that are followed by fishermen in these villages, they are also diverse. However, almost all informant fishermen recognize and describe the pattern of fishermen's participation in their area in sociopolitical organizations is very rare. Some informants only mentioned the recitation groups in a small mosque (musala) around their neighborhood besides the fishing groups that they formed themselves, even though they would only be active when there was a government assistance program. Only one informant explained the communication activities and political lobbying carried out against the government and legislators to empower themselves, their groups and their relationships with fishermen in other dusun. The social organization that they form in a fishermen group does not have an adequate institutional capacity to deal with the policy system. Weak bonds of interest and short-term in the fishing group organizations make this organization vulnerable to quitting after getting help. This also becomes a problem for the Local Government in involving fishermen groups in the development policy process. 


\section{B. The Meninting Fishermen Identification on Coastal Tourism Potency}

The Meninting Coast is located exactly on the west side of the entrance to the Senggigi Beach tourist area. For outside visitors, this beach seems to be covered by a solid line of fishing houses that can be accessed by a road without signposts of the object's beach area. Therefore, the tourism potential of the Meninting beach area was initially only enjoyed by residents.

The most visited location of Meninting beach is located in Dusun Meninting Buwuh. This location is known as Montong Beach. Every Sunday after the dawn prayer, this location will be crowded by teenagers and families who enjoy the view of the west coast that has not been exposed to sunlight so that it presents a beautiful view of the sea and sky, coupled with the waves that are not so big and used as a place for families to relax. Recreational activities undertaken by visitors on this beach have not been so diverse. Generally, just enjoy the view of the beach by sitting on the beach and occasionally swimming. On Sundays, there will be more activities in the morning walking or running because the road along the edge has been rebranded by the Meninting Local Government.

Even though this beach has not provided a proper sanitation system including the unavailability of public toilets and sand filled with rubbish, this beach is never empty by visitors, especially on weekends. The exception is if the tidal waves hit the west coast of Lombok Island.

Montong Beach is starting to feel the economic impact of Tanjung Bias Beach tourism activities in Senteluk Village which has been better managed and made a tourist attraction, which is becoming widely known around Senggigi. At present several seafood stalls have been run which are better managed by residents on Montong Beach. These stalls provide more complete facilities such as toilets and prayer rooms and interesting photo spots. However, visitors still have to familiarize themselves with the amount of garbage and the lifestyle of local people who are not yet aware of the economic value of tourism. Now and then visitors are forced to witness residents throwing the trash into the sea. The lack of cleanliness facilities related to rubbish and dirty Montong coastline shows that this beach has not been prepared to be a professionally managed tourist attraction.

Meanwhile, the Local Government has begun to disseminate information about beach objects through mass media and other media such as billboards in front of the village administration office for an annual event that is worthy of recreation. While at the beach location, there are only levies collection activities for motorized vehicles managed by Dusun Meninting Buwuh youth.

The Local Government has not invited foreign investors to participate in managing the attractions they have because there are still several spatial issues that must be clarified before village resources are deployed for the development of attractions in the region. Some of the problems are (1) clarity of ownership of several plots of land on the beach that involve outsiders, (2) the concept of management of the Meninting estuary has not been agreed as a tourist attraction, and (3) the unclear pattern of contribution of culinary stalls that have stood on the edge the beach managed by several fishing families.

Meninting fishermen live amid stretching coastal tourism activities. Even their neighboring village in 2019 was inaugurated by the central government as one of the coastal tourism destinations with the concept of a fishing village namely Tanjung Bias Beach. However, no informant has a perspective on the opportunities of developing the Tanjung Bias Beach tourist destination. Even an informant who is a big fisherman and at the same time a village official views that the development of Tanjung Bias tourism does not benefit many fishermen in the vicinity. Even though Tanjung Bias Beach can only be accessed by four-wheeled motorized 
vehicles through Dusun Meninting Buwuh. This means that Meninting Village becomes an increasingly strategic tourist destination entrance today. However, welfare opportunities that can be captured by Meninting fishermen have not yet been fully responded to. Some of the causes are: (1) The low capacity of fishermen's resources in producing tourism products, (2) The low capacity of fishermen's resources in influencing or determining the direction of development of tourism destinations, and (3) The concept of development of tourism in Meninting is not yet involved in local fishing groups.

If we look closely, Meninting fishermen are currently outside the tourist destination development policy process. This is because their resources and production activities are significantly lacking in their involvement in tourism activities that are starting to develop there. However, coastal tourism activities have yet to show a loss to their economy. To be involved or involved in the development of Meninting coastal tourism, fishermen's resource capacity requires leveraging through several social engineering. The fishermen group is a potential party as the recipient of the investment or better still a player in tourism production in Meninting.

The fishermen is involved in developing coastal tourism destinations according to aspects of something to see, something to do, and something to buy, is still at the most basic readiness. Fishermen who live in facing the sea can only mention the blessings of welfare they can take from developing coastal tourism even though they can watch the flow of tourist visits every day from their homes. They, with a portrait of their life and livelihood, are only able to present tourist experiences about daily fishing activities, try the simple fishing experience from the beach or just buy fresh or simple processed fish such as boiled or grilled fish.

The informant who has the most resources explained that tourism development concept had been agreed by the Central Government along with the Municipality of Mataram city and the Government of West Lombok Regency in the estuary area of Kali Meninting and the plan to develop a surfing destination did not reflect the placement of fishermen as one of the main actors. The development requires more non-fishing investors with capital that is not currently owned by Meninting fishermen. While the institutional aspects needed to build coastal tourism destinations involving fishermen have not been fulfilled by the Local Government because the basis for establishing institutions derived from data from fishermen and fishermen groups is not yet available.

\section{Meninting Fishermen Accessibilities for Coastal Tourism Development Policy}

Fishermen Meninting in the context of the policy of developing coastal tourism destinations is a strategic interest group for the Local Government. From the spatial geographical aspect, coastal tourism locations are in direct contact with the living space of fishermen where they carry out daily activities interacting with the community and the sea. From the socio-economic aspect, fishing groups have potential as producers of tourism products or services. The accessibility of fishermen to tourism development policies in Meninting will determine how the concept of tourist destinations developed by the Local Government and how successful the key actors of the policy achieve their goals.

If you look closely, Meninting fishermen currently have not reached the level of promoters. This is because the resources owned and the influence of the fishermen groups on the village policy system are still inadequate. Owner fishermen and financier fishermen are more accurately described as a group of defenders, especially those who live in coastal areas. This is because the fishermen group has not become a solid group because of frequent changes in membership formation and most groups disband when they have received capital from the government. Some fishermen owners and investors are also latent stakeholders. Some 
informants showed how their interactions with Local Government in the context of tourism destination development policies were not yet intense in urging or at least conveying their ideas, even though the informants were community leaders included in Local Government structures such as head of the village and members of the Village Consultative Body (Indonesian: Badan Permusyawaratan Desa or BPD) also as fishermen.

In another case, specifically, this category is very identical to the apathetic stakeholder category. The flexibility of their livelihoods to the sea, so this group is described as those who are often seasonal or even very easily stop being fishermen or change jobs, make their interests are not strong against the possibility of them benefiting from tourism development policies even if the policies are in their living areas on the coast and related to their livelihood and interactions with the sea. Fishermen with these characteristics generally live in that are not directly facing the sea and still have other natural resources such as rice fields and plantations.

Likewise, the lack of knowledge resources, the ability to use technology, capital ownership, etc. makes it difficult to have a direct social and political influence on Local Government policies. The accessibility of fishermen as stakeholders to the policy of developing tourist destinations can also be described in several aspects. From the aspect of the personal interests of each fisherman, there is no concrete picture of the idea of fishermen who represent their desires for the development of coastal tourism destinations, even those who live in seaside villages. While from the aspect of knowledge on policy issues, most fishermen are not aware of any policy agenda for developing coastal tourism destinations, except fishermen who happen to be community leaders or Local Government officials who have direct political access to the government. In terms of resources, Meninting fishermen are still very limited socially and economically. There are only five fishermen owners and investors who can be mentioned by the informants. Even then, there are financier fishermen who in the latest development admit that they are forced to sell aid ships from the KKP because they do not match the specifications of the current ocean conditions where they catch fish, while the rest is labor fishermen. From the aspect of the ability to mobilize resources, only the owner fishermen and/or financiers who happen to be figures or become Local Government officials can mention how their activities conveyor push fishermen's ideas and interests. This group illustrates how they become agents for labor fishermen in accessing policies. In terms of its position on the issue of coastal tourism development policy, owner fishermen and financiers show a supportive or neutral reaction. This is because the concept of a tourist destination has not been so concretely scheduled by the Local Government. While labor fishermen tend to show a neutral position because they have not been well-informed about the policy agenda. There was no rejection of the policy agenda, both from investors, owners and fishermen.

\section{Conclusion}

Fishing communities in the Meninting Village spread over five dusun (sub-village), they are; Dusun Meninting Buwuh, Dusun Kongok, Dusun Peresak, Dusun Tegal, and Dusun Pelempat. However, the distribution of ownership of fishermen's social-economic resources in each dusun to access tourism development policy resources in the Meninting village is uneven. Issues of capital control, knowledge and skills, ownership of production equipment, use of science and technology, the introduction of economic opportunities from tourism, fishermen's social-political relations and diversification of catch production differ in each dusun. Fishermen who live in coastal villages have better social resources than fishermen who are far from the coast. Thus, this spatial setting distinguishes their perceptions and ideas about coastal tourism development compared to fishermen in other dusun. The accessibility of

Copyright $\odot$ 2019. Owned by Author(s), published by Society. This is an open access article under CC-BY-NC-SA license.

https://doi.org/10.33019/society.v7i2.101

131 
fishing groups is limited in the development policy. Fishers who deal directly with the sea have a stronger interest in marine economic activity. But the social resources they have are not enough to determine the concept of coastal tourism development that benefits them. Meninting fishermen are still dominant as defenders, latent or even apathetic. The Meninting fishermen have not yet reached the position of the promoter in the tourism development program in their village because they have not shown any success in determining or coloring the development programs formulated by the Local Government so far.

This study recommends some operational suggestions. For the academic community, especially researchers, studies of the community characteristics in certain areas need to be juxtaposed with spatial studies due to social responses that have a certain spatial environment background. Thus social mapping can provide an understanding of the relationship between regional aspects with certain social features. While for the Meninting Local Government it is necessary to build the institutional capacity of fishermen groups so that there is a long-term bond of interest in village development and the Meninting Local Government can make appropriate and effective policy engineering through (1) Identification and categorization of the capacity of fishing groups, (2) Intergroup coaching programs where a group of fishermen with good capacity in the coastal area carries out activities and fostering a group of fishermen with less capacity in a dusun that is far from the coast, (3) Institutional engineering by making the fishermen group, as well as the Tourism Awareness Group, especially fishermen residing in the seaside which routinely interacts with beach tourism activities, (4), Explores the partnership of fishermen groups between coastal tourism villages to strengthen the capacity of fishermen's resources as an interest group in tourism development policies in Meninting Village, and (5) Increases sum economic-social empowerment of fishermen. Apart from the fishermen's resource capacity, the Meninting Local Government in the future needs to formulate a concrete Meninting coastal tourism program that is sourced from strengths or strengths of the socio-economic aspects of their life in the village.

\section{Acknowledgement}

The author would like to thank the Directorate General of Research Strengthening and Development for funding support and facilities for making this study a success through Beginner Lecturer Research Grant Scheme (Indonesian: Hibah Penelitian Dosen Pemula (112/SP2H/PPM/DRPM/I/2019, 0838/L8/KM/2019)), awarded by the Ministry of Research, Technology and Higher Education of the Republic of Indonesia. The Author also want to thank all the informants, village officials of Meninting Village, Batulayar District, West Lombok Regency, West Nusa Tenggara Province, Indonesia.

\section{References}

Alemie, B. K., Bennett, R. M., \& Zevenbergen, J. (2015). A socio-spatial methodology for evaluating urban land governance: the case of informal settlements. Journal of Spatial Science, 60(2), 289-309.

Badan Pusat Statistik. (2012). Jumlah Lapangan Kerja Kepala Rumah Tangga 30 Persen Termiskin Indonesia per Juli 2012.

Batulayar News. (2016, 02 17). Penempatan Tenaga Kerja Asing di Daerah Wisata. Retrieved 08 17, 2019, from http:// batulayarnews.blogspot.com/2016/02/penempatan-tenaga-kerja-asingdi-daerah.html\#more.

Copyright (C 2019. Owned by Author(s), published by Society. This is an open access article under CC-BY-NC-SA license. 
Community Tools Box, Center for Community Health and Development at the University of Kansas. Section 8. Identifying and Analyzing Stakeholders and Their Interests. Retrieved 09 02, 2019 from https://ctb.ku.edu/en/table-of-contents/participation/encouraginginvolvement/identify-stakeholders/checklist.

Dunn, W. N. (2000). Public Policy Analysis: An Introduction. Third Edition. New Jersey: Prentice Hall.

Fitriyah, K., \& Widodo, D. (2016). Karakteristik Sosial Budaya Dan Ekonomi Nelayan Kecil Di Wilayah Pesisir Desa Puger Wetan Kecamatan Puger Kabupaten Jember. Jurnal Pendidikan Ekonomi: Jurnal Ilmiah Ilmu Pendidikan, Ilmu Ekonomi dan Ilmu Sosial, 10(1).

Forster, R., \& Osterhaus, J. (2011). Target Group Analysis: What for, When, What and How?. Retrieved 08 22, 2018 from http://www.mekonginfo.org/assets/midocs/0001933-societytarget-group-analysis-what-for-when-what-and-how.pdf.

Haryani, H. (2014). Potensi Pengembangan Atraksi Wisata Kampung Nelayan Pasie Nan Tigo Kota Padang Ditengah Ancaman Bencana Abrasi Dan Banjir. MIMBAR: Jurnal Sosial dan Pembangunan, 30(2), 189-198.

Haryani; H., \& Huda, N. (2016, October). Potensi Pengembangan Wisata Kampung Nelayan Dengan Partisipasi Masyarakat Sebagai Destinasi Wisata Baru. National Conference of Applied Sciences, Engineering, Business and Information Technology. Politeknik Negeri Padang (pp. 167-176). ASCNI-Tech.

Herison, A., Romdania, Y., \& Yosua, W. B. (2018). Analisis Zonasi Ekowisata Bahari Berbasis Sistem Informasi Geografis. Jurnal SPATIAL Wahana Komunikasi dan Informasi Geografi, 18(2), 95-104.

Kalaiselvan, G., \& Dongre, A. R. Sharing an Experience of Social Mapping Exercise at Perirural Area of Puducherry: 2012: Nat. J. Res. Com. Med, 1(2), 76-79.

Keluargaharapan.com. (2016, 10 02). 14 Kriteria Miskin Menurut Standar BPS. Retrieved 08 18, 2019, from http:/ / keluargaharapan.com/14-kriteria-miskin-menurut-standar-bps/.

Kementerian Kelautan dan Perikanan Republik Indonesia. (2018, 01 12). DJPT KKP Siapkan Program Prioritas bagi Nelayan Indonesia. Retrieved 08 18, 2019, from http://news.kkp.go.id/index.php/djpt-kkp-siapkan-program-prioritas-bagi-nelayanindonesia/.

Mongabay.co.id (2017, 08 02). Sejahterakan Pesisir, Negara Gandeng Nelayan untuk Kembangkan Wisata Bahari. Retrieved 10 16, 2019, from https://www.mongabay.co.id/2017/02/08/sejahterakan-pesisir-negara-gandengnelayan-untuk-kembangkan-wisata-bahari/.

Moore, S. A., Brown, G., Kobryn, H., \& Strickland-Munro, J. (2017). Identifying conflict potential in a coastal and marine environment using participatory mapping. Journal of environmental management, 197, 706-718.

Policy Circle. (2019). Policy Stakeholders Analysis Tool. Retrieved 09 02, 2019, from http://www.policyproject.com/policycircle/content.cfm?a0=3a.

Pos Bali. (2017, 12 17). Desa Meninting Gelar Festival 'Bekele' Tongkol. Retrieved 08 17, 2018, from https:// www.posbali.id/desa-meninting-gelar-festival-bekele-tongkol/.

Pratiwi, A. F. (2014). Pengaruh Pengembangan Wisata Bahari Terhadap Aktivitas Perikanan Dan Strategi Nafkah Nelayan Tanjung Benoa. Skripsi. Departemen Sains Komunikasi dan Pengembangan Masyarakat Institut Pertanian Bogor. (Unpublished).

Radar Lombok. (2017, 02 24). Relokasi Meninting, Warga akan Didata. Retrieved 04 14, 2018, from https://radarlombok.co.id/relokasi-meninting-warga-didata.html.

Copyright (C 2019. Owned by Author(s), published by Society. This is an open access article under CC-BY-NC-SA license. https://doi.org/10.33019/society.v7i2.101 
Radar Lombok. (2017, 10 30). Potensi Objek Wisata Pantai Kongok Menting, Batulayar Digemari Wisatawan untuk Surfing, Minim Perhatian dari Pemda. Retrieved 08 17, 2018, from https://radarlombok.co.id/potensi-objek-wisata-pantai-kongok-menting-batulayar.html.

Royandi, E., Satria, A., \& Saharuddin, S. (2019). Kelompok Kepentingan Dan Relasi Kuasa

Dalam Pengelolaan Sumber Daya Laut Palabuhanratu. Jurnal Kebijakan Sosial Ekonomi Kelautan dan Perikanan, 8(2), 163-173.

Satu Data Indonesia. (2012). Jumlah Nelayan Nasional. Retrieved 08 18, 2018.

Safiullin, M. R., Ermolaeva, P. O., Yermolaev, O. P., \& Selivanov, R. N. (2015). Current perspectives on social mapping of urban territories. Asian social science, 11(6), 207.

Saleha, Q. (2013). Kajian Struktur Sosial dalam Masyarakat Nelayan di Pesisir Kota Balikpapan. Buletin PSP, 21(1), 67-75.

Saribanon, N., et al. (2015). Gilireng dalam Perspektif Pemetaan Sosial. Jakarta: Energy Equitic Epic (Sengkang) Pty. Ltd dan Institut Pengembangan Masyarakat.

Scott, N. (2017). Developing Halal Tourism in Lombok. Proceeding The $1^{\text {st }}$ International Conference On Managing Sustainable Tourism "Indigenous, Authentic And Halal Tourism", Senggigi Lombok, Indonesia: Lembaga Penerbit BP2EB Fakultas Ekonomi dan Bisnis Universitas Mataram.

Sunaryo, B. (2013). Kebijakan Pembangunan Destinasi Pariwisata, Konsep dan Aplikasinya di Indonesia. Yogyakarta: Penerbit Gava Media.

Tatali, A. A., Lasabuda, R., Andaki, J. A., \& Lagarense, B. E. (2018). Strategi Pengembangan Pariwisata Pesisir Di Desa Bentung Kabupaten Kepulauan Sangihe Provinsi Sulawesi Utara. Jurnal Kebijakan Sosial Ekonomi Kelautan dan Perikanan, 8(1), 53-62.

Wiratma, M. (2010). Social Mapping untuk Mengantisipasi Potensi Konflik Di Pertambangan Batubara Kabupaten Kutai Barat, Kaltim. Humaniora, 1(2), 760-777.

World Bank. (2007, 07 25). Tool Name: Social Mapping. Retrieved 08 18, 2018.

Zamzami, L. (2016). Partisipasi Masyarakat Nelayan Dalam Pengembangan Budaya Wisata Bahari di Kabupaten Agam. Jurnal Antropologi: Isu-Isu Sosial Budaya, 17(2), 131-144.

\section{About the Author}

Evi Sukmayeti holds Master of Public Administration from Faculty of Social and Political Sciences, Gadjah Mada University, Yogyakarta, Indonesia, in 2008. Evi Sukmayeti is a lecturer in the department of Public Administration, Mataram Institute of Administrative Sciences, Mataram, West Nusa Tenggara, Indonesia. Recently she is a head of Research and Community Service Center (Indonesian: Pusat Penelitian dan Pengabdian kepada Masyarakat or P3M) at the institute. The author has published some articles in Journal of Governance and Public Policy, Universitas Muhammadiyah Yogyakarta, Indonesia, and Book Chapter "Marrying Young in Indonesia: Voice, Law and Practices" published by Faculty of Law, University of Indonesia cooperated with Van Vollen Hoven Institute of Leiden University, Netherland. 